The effect of organizational culture on strategic thinking - field study ...

Dr/ Amira Said Mohamed Gadelrab

\title{
The effect of organizational culture on strategic thinking - field study on petroleum companies in Egypt-
}

\section{Amira Said Mohamed Gadelrab \\ Faculty of commerce, Suez Canal University Ismailia, Egypt}

\begin{abstract}
:
This research investigate the relation between organizational culture and strategic thinking.

It depend on 16 hypotheses which were refused and accept the alternative hypotheses . the research depend on three companies in petroleum sector in Egypt.
\end{abstract}

\section{Introduction:}

The world is witnessing many huge sophistications and technological changes . organization culture in that it is the main source for providing company with information necessary to make its decisions . there is no doubt that organizational culture has become an important tool in companies, as they represent a major intergradient for services provided by these companies and it has become one of the main features of any company that aspire to confirm it existence . at local and international level it is worth noting that the role of organizational culture is not completed unless there is a senior management that believes in its roles and appreciate its importance as necessary means and advancements.

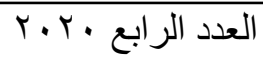

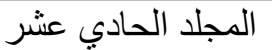


The effect of organizational culture on strategic thinking - field study ...

Dr/ Amira Said Mohamed Gadelrab

Strategic thinking has been reflected in the development of economic activities in general and companies in particular and the services that emerged from it require marketing using the communication and strategic thinking.

\section{Literature review:}

\section{Organizational culture :}

Herskowits conceived a wider definition of culture by suggesting that culture was a »human-made part of the environment « (Herskowits, 1955).

Organizational culture is the collective effect of the common beliefs, behaviours, and values of the people within a company. Those norms within any organization regulate how employees perform and serve customers, how they co-operate with each other, whether they feel motivated to meet goals, and if they are sincerely into the company's overall mission. How are employees getting their work done? Independently or collaboratively? Do employees feel inspired, committed, and engaged, or annoyed, overworked, and underappreciated? (Groysberg, Lee, Price \& Cheng, 2018)

When we talk about organizational culture, we are talking about the employee experience, the internal view. What do the employees think? What is it like, to work here? How can the leadership keep them engaged, loyal, and devoted? Organizational culture, the employee experience, is a steady

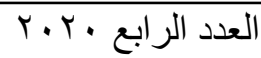

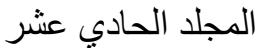


The effect of organizational culture on strategic thinking - field study ...

Dr/ Amira Said Mohamed Gadelrab

setting for every organization's daily operations. (inholland,2018)

Organizational culture tends to be unique to a particular organization, composed of an objective and subjective dimension, and concerned with tradition and the nature of shared beliefs and expectations about organizational life. It is a powerful determinant of individual and group behavior. Organizational culture affects practically all aspects of organizational life from the way in which people interact with each other, perform their work and dress, to the types of decisions made in a firm, its organizational policies and procedures, and strategy considerations (Buono et al., 1985, p. 482).

Organizational or corporate culture is the pattern of values, norms, beliefs, attitudes and assumptions that may not have been articulated but shape the ways in which people in organi- zations behave and things get done. '

The culture of an organization refers to the unique configuration of norms, values, beliefs and ways of behaving that characterize the manner in which groups and indi- viduals combine to get things done. Eldridge and Crombie (1974)

Culture is a system of informal rules that spells out how people are to behave most of the time. Deal and Kennedy (1982)

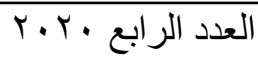
المجلد الحادي عشر 
The effect of organizational culture on strategic thinking - field study ...

Dr/ Amira Said Mohamed Gadelrab

A pattern of basic assumptions - invented, discovered or developed by a given group as it learns to cope with the problems of external adaptation and internal integration - that has worked well enough to be considered valid and, therefore, to be taught to new members as the correct way to perceive, think and feel in relation to these problems. Schein (1985)

Culture is the commonly held beliefs, attitudes and values that exist in an organization. Put more simply, culture is 'the way we do things around here'. Furnham and Gunter (1993)

Martins and Martins (2003, p 380) state the general definition of organisational culture as "a system of shared meaning held by members, distinguishing the organisation from other organisations".

Arnold (2005, p 625) indicates that "organisational culture is the distinctive norms, beliefs, principles and ways of behaving that combine to give each organisation its distinct character". These two definitions suggest that organisational culture distinguishes one organisation from another organisation. Therefore, organisational culture is to an organisation what personality is to an individual (Johnson, 1990).

schein (1985, p 9) also defines organisational culture as "a pattern of basic assumptions invented, discovered, or developed

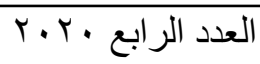

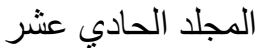


The effect of organizational culture on strategic thinking - field study ...

Dr/ Amira Said Mohamed Gadelrab

by a given group as it learns to cope with its problems of external adaptation and internal integration that has worked well enough to be considered valid, and therefore, to be taught to new members as the correct way to perceive, think, and feel in relation to those problems".

rown (1998, p 9) defines organisational culture as "the pattern of beliefs, values and learned ways of coping with experience that have developed during the course of an organisation's history, and which tend to be manifested in its material arrangements and in the behaviours of its members".

There is no single definition for the concept of the organizational culture. Instead, there are several. For instance, "the process of thinking helps in establishing one member from another on the basis of cognitive thinking" (Geert, et al., 2010)

"the success guidance based upon different values and norm that makes culture effective" (Schein, 2004); "the set of beliefs, behavior, norms and values helps in making culture most effective" (Kotter, et al., 1992).

The term "organizational culture," or "company culture," is a relatively recent addition to our vocabulary from the 1980s. Most simply, organizational culture involves how an organization functions and expresses itself. (Gaalup ,2013)

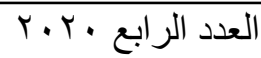

المجلد الحادي عشر 
The effect of organizational culture on strategic thinking - field study ...

Dr/ Amira Said Mohamed Gadelrab

Strategic thinking :

Mintzberg $\square$ 1987a) puts forward five formal definitions of strategy: plan; ploy; pattern; position; and perspective. For most people, strategy is generally perceived as a plan, a consciously intended course of action that is premeditated and deliberate. Planned strategies can be general or specific. Strategy can also be viewed as a pattern "in a stream of actions" taken by members of an organisation. If strategy as plan refers to deliberate, intended strategy that may or may not be realised, then strategy as pattern suggests unplanned, emergent strategyĐpatterns or consistencies that are realised despite, or in the absence, of intentions $\square$ Mintzberg and Waters, 1985).

Bonn (2001) suggests that organizations that successfully develop and integrate strategic thinking at individual and organizational levels can create a core competency[1] that becomes the basis of enduring competitive advantage. Seen from this perspective, the role of strategic thinking has to become central for the future health of a business.

The importance and relevance of this capability is highlighted by Liedtka (1998). He argues that in the face of an unpredictable, highly volatile and competitive market place, a capacity for divergent strategic thinking at multiple organization levels is seen as "central to creating and sustaining competitive

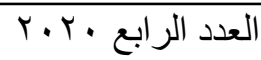
المجلد الحادي عشر 
The effect of organizational culture on strategic thinking - field study ...

Dr/ Amira Said Mohamed Gadelrab

advantage." It follows, therefore, that organizations would bene®t highly from encouraging and helping to develop strategic thinking in as large a number of their employees as practicable.

Other authors have focused on strategic management processes. Some of them stated explicitly that good strategic planning contributes to strategic thinking (Porter, 1987); and some assumed implicitly that a well designed strategic management system facilitates strategic thinking within an organization (Thompson and Strickland, 1999; Viljoen, 1994). Garratt (1995) defined strategic thinking as a process by which senior executives "can rise above the daily managerial processes and crises"' (p. 2) to gain a different perspective of the organization and its changing environments. Heracleous (1998) suggests that strategic thinking and strategic planning are interrelated and equally important for effective strategic management. Thompson and Strickland (1999) concur and state that a well-designed strategic management system facilitates strategic thinking within the organization. (Abbas Monnavarian, Gita Farmani and Hajar Yajam)

For the past 25 years, studies have identified top leaders' absence of strategic thinking as a major detractor of organizational performance (Bonn, 2001; Essery, 2002; Mason, 1986; Zabriskie and Huellmantel, 1991).

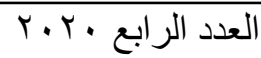

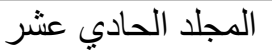


The effect of organizational culture on strategic thinking - field study ...

Dr/ Amira Said Mohamed Gadelrab

The concept of strategic thinking and its importance is discussed in the extant literature (Table AI), it can be defined as the attitude of an organisational thinking process which drives smart actions and the will to inspire the entire firm to work towards a goal (Hamel and Prahalad, 1994; Mintzberg, 1987; Bonn, 2005; Alsaaty, 2007; Dhir et al., 2018; Dhir, 2016, 2017), achieving the competitive advantage over the competitors and asserting an act of creating a new business venture (Shaheen et al., 2012; Kazmi and Naaranoja, 2015).

Research objectives :

1- Explore the relationship between strategic thinking and organizational culture

2- Explore the relation between strategic dimension, value dimension, symbols, and support dimension and thinking in time, thinking in opportunities, depending on hypotheses and systematic thinking .

Research methodology:

The researcher used two types of data as follow:

First: study methodology

a- Secondary resources:

The researcher depends on Arabic and English books and scientific journals which research in the topic of the study, and the researcher depends on published and unpublished 
The effect of organizational culture on strategic thinking - field study ...

Dr/ Amira Said Mohamed Gadelrab

secondary data backing to libraries in which the researches lies between 2010 and 2020.

b- Primary resources: the primary data was collected from all the employees in petroleum companies. , to get their opinions which serve the research topic to test the hypotheses in addition to make interviews as follows:

1- Questionnaire : the questionnaire was designed to know employees directions in petroleum companies in Egypt, the questionnaire was prepared to include all the study variables and its classified into two parts as follow:

First part: the part of organizational culture dimensions. Second part: the part of strategic thinking dimensions.

2- The interviews: the researcher depends on making interviews to get answers for some information and data and notes from interviewee .

3- Analytical study: the questionnaire was analyzed to get the finding and recommendations.

Second: study population and sample:

1- Study population:

The study population is all the employees that works in petroleum companies in Egypt which is 13451 unit and this according to data in 2019.

2- Study sample:

From the sample table study sample is $\mathbf{3 7 3 . 5}$

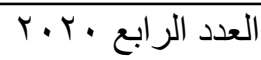
المجلد الحادي عشر 
The effect of organizational culture on strategic thinking - field study ...

Dr/ Amira Said Mohamed Gadelrab

Third : validity and reliability variables for questionnaire :

a- Validity :

From analysis revealed that validity variable for each dimension of the study greater than .60 and validity for all the questionnaire is .901 which is high rate of validity.

Table 1

\begin{tabular}{|l|l|l|l|l|}
\hline $\mathrm{N}$ & Dimensions & Validity & Reliability & Paragraphs number \\
\hline 1 & Strategic dimension & .712 & .844 & 5 \\
\hline 2 & Values dimension & .742 & .861 & 5 \\
\hline 3 & Symbols & .692 & .832 & 5 \\
\hline 4 & Support & .681 & .825 & 5 \\
\hline 5 & Thinking about time & .689 & .830 & 5 \\
\hline 6 & $\begin{array}{l}\text { Thinking about } \\
\text { opportunities }\end{array}$ & .788 & .888 & 5 \\
\hline 7 & $\begin{array}{l}\text { Depending on } \\
\text { hypotheses }\end{array}$ & .802 & .896 & 5 \\
\hline 8 & Systematic thinking & .853 & .924 & 5 \\
\hline & Questionnaire & .901 & .949 & 40 \\
\hline
\end{tabular}

b- Reliability: the reliability is .60 for each dimension of dimensions of the study and reliability for the questionnaire as a whole is .949 and this consider a good rate which mean that questionnaire is reliable to measure each dimension.


المجلد الحادي عشر 
The effect of organizational culture on strategic thinking - field study ...

Dr/ Amira Said Mohamed Gadelrab

Forth: study limitations :

The human limitations:

The field study is on the employees of the companies ( top, middle and bottom line management) at three companies of petroleum in Egypt.

The spatial limitation:

The study was applied on three companies of petroleum in Egypt. Time limitation:

The data was collected between June 2020 and July 2020

Fifth : hypotheses testing :

Null hypothesis: there is no significant relation between

organizational culture and strategic thinking.

The first sub hypothesis :

There is no significant relation between strategic dimension and thinking in time .

To test this hypothesis the researcher conducted the following tests:

a- Correlation

table 2

\begin{tabular}{|l|l|l|l|}
\hline Variable & Test & Strategic dimension & Thinking about time \\
\hline $\begin{array}{l}\text { Strategic } \\
\text { dimension }\end{array}$ & Pearson correlation & 1 & .553 \\
\hline & Sig. & 0.000 & 0.000 \\
\hline
\end{tabular}

This table emphasize that there is statistical relation at percent $55.3 \%$ at significant level .05 between the two variables .

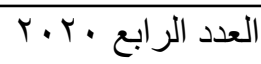
المجلد الحادي عشر 
The effect of organizational culture on strategic thinking - field study ...

Dr/ Amira Said Mohamed Gadelrab

b- Model summary:

table3

\begin{tabular}{|l|l|l|l|}
\hline $\begin{array}{l}\text { Independent } \\
\text { variable }\end{array}$ & R Square & Adjusted R square & $\begin{array}{l}\text { Std . Error of the } \\
\text { estimate }\end{array}$ \\
\hline Strategic dimension & 0.305 & 0.303 & 3.32997 \\
\hline
\end{tabular}

The previous table clarify that $\mathrm{R}^{2}=.305$ which mean that strategic dimension explain the change in thinking in time at percent $30.5 \%$, the remaining percent explained by another variables.

c- ANOVA Test:

Table4

\begin{tabular}{|c|c|c|c|c|c|}
\hline Sig. & F & Mean Square & Df & Sum of Squares & Model \\
\hline \multirow{3}{*}{0.000} & \multirow{3}{*}{139.799} & 1550.189 & 1 & 1550.189 & Regression \\
\cline { 3 - 6 } & & 11.089 & 318 & 3526.199 & Residual \\
\cline { 3 - 6 } & & 319 & 5076.387 & Total \\
\hline
\end{tabular}

The previous table clarify that there is positive relation between strategic dimension and thinking in time which explained by the value of $F$ which have significant level .05 .

d- Regression analysis:

table 5

\begin{tabular}{|c|c|c|c|c|c|c|}
\hline \multirow[t]{2}{*}{ Sig. } & \multirow[t]{2}{*}{$\mathrm{T}$} & \multirow{2}{*}{$\begin{array}{c}\begin{array}{c}\text { Standardized } \\
\text { Coefficients }\end{array} \\
\text { Beta }\end{array}$} & \multicolumn{2}{|c|}{ Unstandardized Coefficients } & \multirow[t]{2}{*}{ The model } & \\
\hline & & & Std. Error & B & & \\
\hline 0.000 & 7.003 & \multirow[b]{2}{*}{0.553} & 0.904 & 6.332 & Constant & \multirow{2}{*}{1} \\
\hline 0.000 & 11.824 & & 0.05 & 0.588 & Strategic dimension & \\
\hline
\end{tabular}

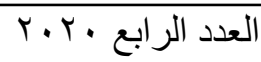


The effect of organizational culture on strategic thinking - field study ...

Dr/ Amira Said Mohamed Gadelrab

The previous table clarify that $\mathrm{T}$ test for strategic dimension have significant level at .05 and that clarify the strong relation between two variables .

We can summarize from the previous table the following:

\# pearson and regression variable less than .05 which mean that there is statistical relation between the two variables .

\# pearson was positive which mean that there is positive relation between the two variables.

\# Beta clarify that independent variable affect the dependent one at different percentage and that is not by chance

\# from previous the researcher can accept the alternative hypothesis:

"there is significant effect between the two variables "

2-Second sub hypothesis :

a- Correlation:

The following table clarify correlation between

strategic dimension as independent variable and

thinking in opportunities as dependent variable Table 6

\begin{tabular}{|c|c|c|c|}
\hline Variable & Test & Strategic dimension & $\begin{array}{c}\text { Thinking about } \\
\text { opportunities }\end{array}$ \\
\hline $\begin{array}{c}\text { Strategic } \\
\text { dimension }\end{array}$ & Pearson correlation & 1 & .535 \\
\hline & Sig. & 0.000 & 0.000 \\
\hline
\end{tabular}

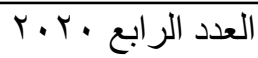

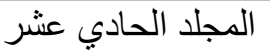


The effect of organizational culture on strategic thinking - field study ...

Dr/ Amira Said Mohamed Gadelrab

And from the previous table there is correlation between two varibales at percentage of $53.5 \%$ at significant level .05.

b- Model Summary:

table 7

\begin{tabular}{|c|c|c|c|}
\hline Independent variable & R Square & Adjusted R square & $\begin{array}{c}\text { Std . Error of the } \\
\text { estimate }\end{array}$ \\
\hline Strategic dimension & .287 & .284 & 3.39069 \\
\hline
\end{tabular}

The previous table clarify that $\mathrm{R}^{2}=.287$ which mean that strategic dimension explain the change in thinking in time at percent $28.7 \%$, the remaining percent explained by another variables.

c- ANOVA Test table8

\begin{tabular}{|c|c|c|c|c|c|}
\hline Sig. & $\mathrm{F}$ & Mean Square & Df & Sum of Squares & Model \\
\hline \multirow{3}{*}{0.000} & \multirow{3}{*}{127.81} & 1469.403 & 1 & 1469.403 & Regression \\
\cline { 3 - 6 } & & 11.497 & 318 & 3655.969 & Residual \\
\cline { 3 - 6 } & & 319 & 5125.372 & Total \\
\hline
\end{tabular}

The previous table clarify that there is positive relation between the two varibles which explained by the value of $F$ which have significant level .05 .

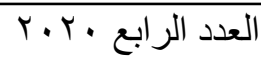

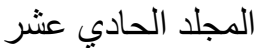


The effect of organizational culture on strategic thinking - field study ...

Dr/ Amira Said Mohamed Gadelrab

d- Regression :

table 10

\begin{tabular}{|c|c|c|c|c|c|c|}
\hline \multirow[t]{2}{*}{ Sig. } & \multirow[t]{2}{*}{$\mathrm{T}$} & $\begin{array}{c}\text { Standardized } \\
\text { Coefficients }\end{array}$ & \multicolumn{2}{|c|}{$\begin{array}{l}\text { Unstandardized } \\
\text { Coefficients }\end{array}$} & \multirow[t]{2}{*}{ Model } & \\
\hline & & Beta & Std. Error & B & & \\
\hline 0.000 & 8.043 & & 0.921 & 7.405 & Constant & \\
\hline 0.000 & 11.305 & 0.535 & 0.051 & 0.573 & $\begin{array}{c}\text { Strategic } \\
\text { dimension }\end{array}$ & 1 \\
\hline
\end{tabular}

The previous table clarify that $\mathrm{T}$ test for strategic dimension have significant level at .05 and that clarify the strong relation between two variables .

We can summarize from the previous table the following:

\# pearson and regression variable less than .05 which mean that there is statistical relation between the two variables .

\# pearson was positive which mean that there is positive relation between the two variables.

\# Beta clarify that independent variable affect the dependent one at different percentage and that is not by chance

\# from previous the researcher can accept the alternative hypothesis:

" there is significant effect between the two variables " 
The effect of organizational culture on strategic thinking - field study ...

Dr/ Amira Said Mohamed Gadelrab

3-Third sub hypothesis:

a- Correlation:

The following table clarify correlation between

Table 11

\begin{tabular}{|l|l|l|l|}
\hline Variable & Test & Strategic dimension & $\begin{array}{l}\text { Thinking about } \\
\text { opportunities }\end{array}$ \\
\hline $\begin{array}{l}\text { Strategic } \\
\text { dimension }\end{array}$ & Pearson correlation & 1 & .535 \\
\hline & Sig. & 0.000 & 0.000 \\
\hline
\end{tabular}

From the previous table its clarify that there is a relation between the two varibles at percentage $51.1 \%$ at significant level .05.

b- Model summary:

table 12

\begin{tabular}{|c|c|c|c|c|}
$\begin{array}{c}\text { Std. Error of the } \\
\text { Estimate }\end{array}$ & $\begin{array}{c}\text { Adjusted R } \\
\text { Square }\end{array}$ & R Square & Model \\
\hline 3.59853 & 0.259 & 0.261 & Strategic dimension \\
\hline & $\begin{array}{l}\text { R } \\
\text { explain the change in the dependent variable at }\end{array}$ \\
percent 26.1 \% \\
c- ANOVA Test: \\
table 13
\end{tabular}
\begin{tabular}{|c|c|c|c|c|c|}
\hline Sig. & F & Mean Square & Df & Sum of Squares & Model \\
\hline \multirow{2}{*}{0.000} & 112.396 & 12.949 & 318 & 4117.924 & Residual \\
\cline { 2 - 6 } & & 1455.463 & 1 & 1455.463 & Regression \\
\cline { 2 - 6 } & & 319 & 5573.387 & Total \\
\hline
\end{tabular}

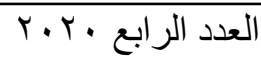
المجلد الحادي عشر 
The effect of organizational culture on strategic thinking - field study ...

Dr/ Amira Said Mohamed Gadelrab

The previous table clarify that there is positive relation between the two varibles which explained by the value of $F$ which have significant level .05 .

d- Regression:

table 14

\begin{tabular}{|c|c|c|c|c|c|}
\hline \multirow[t]{2}{*}{ Sig. } & \multirow[t]{2}{*}{$\mathrm{T}$} & $\begin{array}{l}\text { Standardized } \\
\text { Coefficients }\end{array}$ & \multicolumn{2}{|c|}{$\begin{array}{l}\text { Unstandardized } \\
\text { Coefficients }\end{array}$} & \multirow[t]{2}{*}{ Model } \\
\hline & & Beta & Std. Error & B & \\
\hline 0.000 & 6.877 & & 0.977 & 6.719 & Constant \\
\hline 0.000 & 10.602 & 0.511 & 0.054 & 0.57 & $\begin{array}{c}\text { Strategic } \\
\text { dimension }\end{array}$ \\
\hline
\end{tabular}

The previous table clarify that $\mathrm{T}$ test for strategic dimension have significant level at .05 and that clarify the strong relation between two variables .

We can summarize from the previous table the following: \# pearson and regression variable less than .05 which mean that there is statistical relation between the two variables . \# pearson was positive which mean that there is positive relation between the two variables.

\# Beta clarify that independent variable affect the dependent one at different percentage and that is not by chance

\# from previous the researcher can accept the alternative hypothesis:

" there is significant effect between the two variables " 
The effect of organizational culture on strategic thinking - field study ...

Dr/ Amira Said Mohamed Gadelrab

4-forth sub-hypothesis:

There is no significant effect to strategic dimension on systematic thinking

a- Correlation:

table 15

\begin{tabular}{|l|l|l|l|}
\hline Variable & Test & Strategic dimension & Systematic thinking \\
\hline $\begin{array}{l}\text { Strategic } \\
\text { dimension }\end{array}$ & Pearson correlation & 1 & .470 \\
\hline & Sig. & 0.000 & 0.000 \\
\hline
\end{tabular}

From the previous table its clarify that there is significant relation between two varibles at percent $47.0 \%$

b- Model Summary:

table 16

\begin{tabular}{|c|c|c|c|}
\hline Std. Error of the Estimate & Adjusted R Square & R Square & Model \\
\hline 3.98482 & 0.218 & 0.221 & $\begin{array}{c}\text { Strategic } \\
\text { dimension }\end{array}$ \\
\hline
\end{tabular}

$\mathrm{R}^{2}=.221$ which mean that the independent variable explain the change in the dependent variable at percent $22.1 \%$.

\section{c- ANOVA Test:}

table 17

\begin{tabular}{|c|c|c|c|c|c|}
\hline Sig. & $F$ & Mean Square & Df & Sum of Squares & Model \\
\hline \multirow{3}{*}{0.000} & \multirow{3}{*}{90.141} & 1431.337 & 1 & 1431.337 & Regression \\
\cline { 3 - 6 } & & 15.879 & 318 & 5049.46 & Residual \\
\cline { 3 - 6 } & & 319 & 6480.797 & Total \\
\hline
\end{tabular}

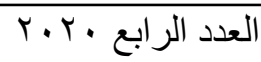
المجلد الحادي عشر 
The effect of organizational culture on strategic thinking - field study ...

Dr/ Amira Said Mohamed Gadelrab

The previous table clarify that there is positive relation between the two varibles which explained by the value of $F$ which have significant level .05

d- Regression :

table 18

\begin{tabular}{|c|c|c|c|c|c|c|}
\hline \multirow[t]{2}{*}{ Sig. } & \multirow[t]{2}{*}{$\mathrm{T}$} & $\begin{array}{c}\text { Standardized } \\
\text { Coefficients }\end{array}$ & \multicolumn{2}{|c|}{$\begin{array}{l}\text { Unstandardized } \\
\text { Coefficients }\end{array}$} & \multirow{2}{*}{\multicolumn{2}{|c|}{ Model }} \\
\hline & & Beta & Std. Error & B & & \\
\hline 0.000 & 7.071 & & 1.082 & 7.651 & Constant & \\
\hline 0.000 & 9.494 & 0.470 & 0.06 & 0.565 & $\begin{array}{l}\text { Strategic } \\
\text { dimesnsion }\end{array}$ & 1 \\
\hline
\end{tabular}

The previous table clarify that $\mathrm{T}$ test for strategic

dimension have significant level at .05 and that clarify the strong relation between two variables .

We can summarize from the previous table the following:

\# pearson and regression variable less than .05 which mean that there is statistical relation between the two variables .

\# pearson was positive which mean that there is positive relation between the two variables.

\# Beta clarify that independent variable affect the dependent one at different percentage and that is not by chance

\# from previous the researcher can accept the alternative hypothesis:

" there is significant effect between the two variables " 
The effect of organizational culture on strategic thinking - field study ...

Dr/ Amira Said Mohamed Gadelrab

5-Fifth sub-hypothsis:

There is no significant relation between value dimension and thinking in time

a- Correlation:

table 19

\begin{tabular}{|c|c|c|c|}
\hline Variable & Test & Value dimension & Thinking in time \\
\hline $\begin{array}{c}\text { Value } \\
\text { dimension }\end{array}$ & Pearson correlation & 1 & .727 \\
\hline & Sig. & 0.000 & 0.000 \\
\hline
\end{tabular}

From the previous table its clarify that there is significant relation between two varibles at percent $72.7 \%$

b- Model summary:

table 20

\begin{tabular}{|c|c|c|l|}
\hline Std. Error of the Estimate & Adjusted R Square & R Square & $\begin{array}{l}\text { Independent } \\
\text { variable }\end{array}$ \\
\hline 2.74143 & 0.528 & 0.529 & $\begin{array}{l}\text { Value } \\
\text { dimension }\end{array}$ \\
\hline
\end{tabular}

$\mathrm{R}^{2}=.529$ which mean that the independent variable explain the change in the dependent variable at percent $52.9 \%$.

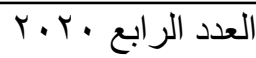

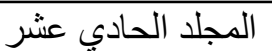


The effect of organizational culture on strategic thinking - field study ...

Dr/ Amira Said Mohamed Gadelrab

\section{c- ANOVA TEST:}

table 21

\begin{tabular}{|c|c|c|c|c|c|}
\hline Sig. & F & Mean Square & Df & Sum of Squares & Model \\
\hline \multirow{3}{*}{0.000} & \multirow{3}{*}{357.463} & 2686.483 & 1 & 2686.483 & Regression \\
\cline { 3 - 6 } & & 7.515 & 318 & 2389.905 & Residual \\
\cline { 3 - 6 } & & & 319 & 5076.387 & Total \\
\hline
\end{tabular}

The previous table clarify that there is positive relation between the two varibles which explained by the value of $\mathrm{F}$ which have significant level .05 .

d- Regression analysis:

table 22

\begin{tabular}{|c|c|c|c|c|c|c|}
\hline \multirow[t]{2}{*}{ Sig. } & \multirow[t]{2}{*}{$\mathrm{T}$} & $\begin{array}{l}\text { Standardized } \\
\text { Coefficients }\end{array}$ & \multicolumn{2}{|c|}{$\begin{array}{l}\text { Unstandardized } \\
\text { Coefficients }\end{array}$} & \multirow[t]{2}{*}{ Model } & \\
\hline & & Beta & Std. Error & B & & \\
\hline 0.000 & 7.212 & & 0.656 & 4.732 & Constant & \\
\hline 0.000 & 18.907 & 0.727 & 0.038 & 0.725 & $\begin{array}{c}\text { Value } \\
\text { dimension }\end{array}$ & 1 \\
\hline
\end{tabular}

The previous table clarify that $\mathrm{T}$ test for strategic

dimension have significant level at .05 and that clarify the strong relation between two variables .

We can summarize from the previous table the following:

\# pearson and regression variable less than .05 which mean that there is statistical relation between the two variables . 
The effect of organizational culture on strategic thinking - field study ...

Dr/ Amira Said Mohamed Gadelrab

\# pearson was positive which mean that there is positive relation between the two variables.

\# Beta clarify that independent variable affect the dependent one at different percentage and that is not by chance

\# from previous the researcher can accept the alternative hypothesis:

" there is significant effect between the two variables "

6-sixth sub hypothesis:

There is no significant relation for value dimension on thinking in opportunities

a- Correlation:

Table 23

\begin{tabular}{|l|l|l|l|}
\hline Variable & Test & Value dimension & Thinking in time \\
\hline Value dimension & $\begin{array}{l}\text { Pearson } \\
\text { correlation }\end{array}$ & 1 & .749 \\
\hline & Sig. & 0.000 & 0.000 \\
\hline
\end{tabular}

From the previous table its clarify that there is significant relation between two varibles at percent $74.9 \%$

b- Model summary:

Table 24

\begin{tabular}{|c|c|c|c|}
\hline Std. Error of the Estimate & $\begin{array}{c}\text { Adjusted R } \\
\text { Square }\end{array}$ & R Square & Model \\
\hline 2.65916 & 0.56 & 0.561 & $\begin{array}{c}\text { Value } \\
\text { dimension }\end{array}$ \\
\hline
\end{tabular}

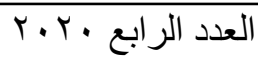
المجلد الحادي عشر 
The effect of organizational culture on strategic thinking - field study ...

Dr/ Amira Said Mohamed Gadelrab

$\mathrm{R}^{2}=.561$ which mean that the independent variable

explain the change in the dependent variable at percent $56.1 \%$.

\section{c- ANOVA TEST:}

table 25

\begin{tabular}{|c|c|c|c|c|c|}
\hline Sig. & \multirow{2}{*}{ F } & $\begin{array}{c}\text { Mean } \\
\text { Square }\end{array}$ & Df & $\begin{array}{c}\text { Sum of } \\
\text { Squares }\end{array}$ & Model \\
\hline \multirow{2}{*}{0.000} & \multirow{2}{*}{406.828} & 2876.744 & 1 & 2876.744 & Regression \\
\cline { 3 - 6 } & & 7.071 & 318 & 2248.628 & Residual \\
\cline { 3 - 6 } & & & 319 & 5125.372 & Total \\
\hline
\end{tabular}

The previous table clarify that there is positive relation

between the two varibles which explained by the value of $\mathrm{F}$ which have significant level .05 .

d- Regression analysis:

table 26

\begin{tabular}{|c|c|c|c|c|c|c|}
\hline \multirow[t]{2}{*}{ Sig. } & \multirow[t]{2}{*}{$\mathrm{T}$} & \multirow{2}{*}{$\begin{array}{c}\text { Standardized } \\
\text { Coefficients } \\
\text { Beta }\end{array}$} & \multicolumn{2}{|c|}{$\begin{array}{l}\text { Unstandardized } \\
\text { Coefficients }\end{array}$} & \multicolumn{2}{|l|}{ Model } \\
\hline & & & Std. Error & B & & \\
\hline 0.000 & 8.028 & & 0.636 & 5.109 & Constant & \\
\hline 0.000 & 20.17 & 0.749 & 0.037 & 0.75 & $\begin{array}{l}\text { Value } \\
\text { dimension }\end{array}$ & 1 \\
\hline
\end{tabular}

The previous table clarify that $\mathrm{T}$ test for independent

variable have significant level at .05 and that clarify the strong relation between two variables .

We can summarize from the previous table the following:

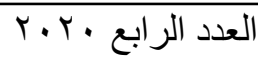
المجلد الحادي عشر 
The effect of organizational culture on strategic thinking - field study ...

Dr/ Amira Said Mohamed Gadelrab

\# pearson and regression variable less than .05 which mean that there is statistical relation between the two variables . \# pearson was positive which mean that there is positive relation between the two variables.

\# Beta clarify that independent variable affect the dependent one at different percentage and that is not by chance

\# from previous the researcher can accept the alternative hypothesis:

" there is significant effect between the two variables "

7-seventh sub-hypothesis:

a- Correlation :

table 27

\begin{tabular}{|l|l|l|l|}
\hline Variable & Test & Value dimension & $\begin{array}{l}\text { Depending on } \\
\text { hypotheses }\end{array}$ \\
\hline Value dimension & $\begin{array}{l}\text { Pearson } \\
\text { correlation }\end{array}$ & 1 & .740 \\
\hline & Sig. & 0.000 & 0.000 \\
\hline
\end{tabular}

From the previous table its clarify that there is significant relation between two varibles at percent $74 \%$

b- Model summary:

table 28

\begin{tabular}{|c|r|r|c|}
\hline $\begin{array}{c}\text { Std. Error of the } \\
\text { Estimate }\end{array}$ & \multicolumn{1}{|c|}{$\begin{array}{c}\text { Adjusted R } \\
\text { Square }\end{array}$} & R Square & Model \\
\hline 2.81421 & 0.547 & 0.548 & Value dimension \\
\hline
\end{tabular}

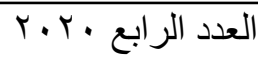
المجلد الحادي عشر 
The effect of organizational culture on strategic thinking - field study ...

Dr/ Amira Said Mohamed Gadelrab

$\mathrm{R}^{2}=.548$ which mean that the independent variable

explain the change in the dependent variable at percent $54.8 \%$.

c- ANOVA Test:

table 29

\begin{tabular}{|c|c|c|c|c|c|}
\hline Sig. & F & Mean Square & Df & Sum of Squares & Model \\
\hline \multirow{3}{*}{0.000} & \multirow{3}{*}{385.729} & 3054.894 & 1 & 3054.894 & Regression \\
\cline { 3 - 6 } & & 7.92 & 318 & 2518.494 & Residual \\
\cline { 3 - 6 } & & 319 & 5573.387 & Total \\
\hline
\end{tabular}

The previous table clarify that there is positive relation between the two varibles which explained by the value of F which have significant level 05 .

d- Regression analysis:

table 30

\begin{tabular}{|c|c|c|c|c|c|c|}
\hline \multirow[t]{2}{*}{ Sig. } & \multirow[t]{2}{*}{$\mathrm{T}$} & $\begin{array}{l}\text { Standardized } \\
\text { Coefficients }\end{array}$ & \multicolumn{2}{|c|}{$\begin{array}{l}\text { Unstandardized } \\
\text { Coefficients }\end{array}$} & \multirow[t]{2}{*}{ Model } & \\
\hline & & Beta & Std. Error & B & & \\
\hline 0.000 & 5.93 & & 0.674 & 3.994 & Constant & \\
\hline 0.000 & 19.64 & 0.74 & 0.039 & 0.773 & $\begin{array}{c}\text { Value } \\
\text { dimesnion }\end{array}$ & 1 \\
\hline
\end{tabular}

The previous table clarify that $\mathrm{T}$ test for independent variable have significant level at .05 and that clarify the strong relation between two variables .

We can summarize from the previous table the following: \# pearson and regression variable less than .05 which mean that there is statistical relation between the two variables . 
The effect of organizational culture on strategic thinking - field study ...

Dr/ Amira Said Mohamed Gadelrab

\# pearson was positive which mean that there is positive relation between the two variables.

\# Beta clarify that independent variable affect the dependent one at different percentage and that is not by chance

\# from previous the researcher can accept the alternative hypothesis:

" there is significant effect between the two variables "

8-Eighths sub-hypothesis:

There is no significant relation between value

dimension and systematic thinking .

a- Correlation :

Table 31

\begin{tabular}{|l|l|l|l|}
\hline Variable & Test & Value dimension & Systematic thinking \\
\hline Value dimension & Pearson correlation & 1 & .787 \\
\hline & Sig. & 0.000 & 0.000 \\
\hline
\end{tabular}

From the previous table its clarify that there is significant relation between two varibles at percent $78.7 \%$

b- Model summary:

table 32

\begin{tabular}{|r|r|r|c|}
\hline Std. Error of the Estimate & Adjusted R Square & R Square & Model \\
\hline 2.78584 & 0.618 & 0.619 & $\begin{array}{c}\text { Value } \\
\text { dimension }\end{array}$ \\
\hline
\end{tabular}

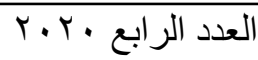
المجلد الحادي عشر 
The effect of organizational culture on strategic thinking - field study ...

Dr/ Amira Said Mohamed Gadelrab

$\mathrm{R}^{2}=. .619$ which mean that the independent

variable explain the change in the dependent

variable at percent $61.9 \%$.

c- ANOVA Test:

table 33

\begin{tabular}{|c|c|c|c|c|c|}
\hline Sig. & F & Mean Square & Df & Sum of Squares & Model \\
\hline \multirow{3}{*}{0.000} & \multirow{3}{*}{517.059} & 4012.835 & 1 & 4012.835 & Regression \\
\cline { 3 - 6 } & & 7.761 & 318 & 2467.961 & Residual \\
\cline { 3 - 6 } & & & 319 & 6480.797 & Total \\
\hline
\end{tabular}

The previous table clarify that there is positive relation between the two varibles which explained by the value of F which have significant level .05 .

d- Regression analysis:

table 34

\begin{tabular}{|c|c|c|c|c|c|c|}
\hline \multirow[t]{2}{*}{ Sig. } & \multirow[t]{2}{*}{$\mathrm{T}$} & $\begin{array}{l}\text { Standardized } \\
\text { Coefficients }\end{array}$ & \multicolumn{2}{|c|}{$\begin{array}{l}\text { Unstandardized } \\
\text { Coefficients }\end{array}$} & \multirow{2}{*}{\multicolumn{2}{|c|}{ Model }} \\
\hline & & Beta & Std. Error & B & & \\
\hline 0.000 & 4.442 & & 0.667 & 2.961 & Constant & \\
\hline 0.000 & 22.739 & 0.787 & 0.039 & 0.886 & $\begin{array}{l}\text { Value } \\
\text { dimension }\end{array}$ & 1 \\
\hline
\end{tabular}

The previous table clarify that $\mathrm{T}$ test for independent variable have significant level at .05 and that clarify the strong relation between two variables .

We can summarize from the previous table the following:

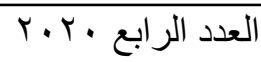
المجلد الحادي عشر 
The effect of organizational culture on strategic thinking - field study ...

Dr/ Amira Said Mohamed Gadelrab

\# pearson and regression variable less than .05 which mean that there is statistical relation between the two variables . \# pearson was positive which mean that there is positive relation between the two variables.

\# Beta clarify that independent variable affect the dependent one at different percentage and that is not by chance

\# from previous the researcher can accept the alternative hypothesis:

" there is significant effect between the two variables "

9- ninth sub-hypothesis:

There no significant relation between symbol dimension and thinking in time .

a- Correlation:

table 35

\begin{tabular}{|l|l|l|l|}
\hline Variable & Test & symbol dimension & Thinking in time \\
\hline symbol dimension & Pearson correlation & 1 & .640 \\
\hline & Sig. & 0.000 & 0.000 \\
\hline
\end{tabular}

From the previous table its clarify that there is significant relation between two varibles at percent $64 \%$

b- Model summary:

table 36

\begin{tabular}{|r|r|r|l|}
\hline Std. Error of the Estimate & Adjusted R Square & R Square & $\begin{array}{l}\text { Independent } \\
\text { variable }\end{array}$ \\
\hline 3.07006 & 0.408 & 0.410 & $\begin{array}{l}\text { Symbol } \\
\text { dimension }\end{array}$ \\
\hline
\end{tabular}

العدد الر ابع • r. الع المجلد الحادي عشر 
The effect of organizational culture on strategic thinking - field study ...

Dr/ Amira Said Mohamed Gadelrab

$\mathrm{R}^{2}=. .410$ which mean that the independent

variable explain the change in the dependent

variable at percent $41 \%$

c- ANOVA Test:

table 37

\begin{tabular}{|c|c|c|c|c|c|}
\hline \multicolumn{1}{|c|}{ Sig. } & F & Mean Square & Df & Sum of Squares & Model \\
\hline \multirow{3}{*}{0.000} & \multirow{3}{*}{220.593} & 2079.147 & 1 & 2079.147 & Regression \\
\cline { 3 - 6 } & & 9.425 & 318 & 2997.24 & Residual \\
\cline { 3 - 6 } & & & 319 & 5076.387 & Total \\
\hline
\end{tabular}

The previous table clarify that there is positive relation

between the two varibles which explained by the value of

$\mathrm{F}$ which have significant level .05 .

d- Regression analysis:

table 38

\begin{tabular}{|c|c|c|c|c|c|c|}
\hline \multirow[t]{2}{*}{ Sig. } & \multirow[t]{2}{*}{$\mathrm{T}$} & $\begin{array}{l}\text { Standardized } \\
\text { Coefficients }\end{array}$ & \multicolumn{2}{|c|}{$\begin{array}{l}\text { Unstandardized } \\
\text { Coefficients }\end{array}$} & \multirow{2}{*}{\multicolumn{2}{|c|}{ Model }} \\
\hline & & Beta & Std. Error & B & & \\
\hline 0.000 & 7.936 & & 0.75 & 5.951 & Constant & \\
\hline 0.000 & 14.852 & 0.640 & 0.043 & 0.642 & $\begin{array}{l}\text { Symbol } \\
\text { dimension }\end{array}$ & 1 \\
\hline
\end{tabular}

The previous table clarify that $\mathrm{T}$ test for independent

variable have significant level at .05 and that clarify the strong relation between two variables .

We can summarize from the previous table the following:

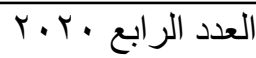




The effect of organizational culture on strategic thinking - field study ...

Dr/ Amira Said Mohamed Gadelrab

\# pearson and regression variable less than .05 which mean that there is statistical relation between the two variables . \# pearson was positive which mean that there is positive relation between the two variables.

\# Beta clarify that independent variable affect the dependent one at different percentage and that is not by chance

\# from previous the researcher can accept the alternative hypothesis:

"there is significant effect between the two variables " 10- tenth sub-hypothesis:

There is no significant relation for symbol dimension and thinking in opportunities .

a- Correlation:

table 39

\begin{tabular}{|l|l|l|l|}
\hline Variable & Test & symbol dimension & $\begin{array}{l}\text { Thinking in } \\
\text { opportunities }\end{array}$ \\
\hline symbol dimension & $\begin{array}{l}\text { Pearson } \\
\text { correlation }\end{array}$ & 1 & .613 \\
\hline & Sig. & 0.000 & 0.000 \\
\hline
\end{tabular}

From the previous table its clarify that there is significant relation between two varibles at percent $61.3 \%$

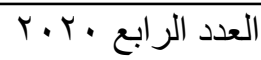
المجلد الحادي عشر 
The effect of organizational culture on strategic thinking - field study ...

Dr/ Amira Said Mohamed Gadelrab

b- Model summary:

table 40

\begin{tabular}{|r|r|r|c|}
\hline Std. Error of the Estimate & Adjusted R Square & R Square & Model \\
\hline 3.17195 & 0.374 & 0.376 & $\begin{array}{c}\text { Symbol } \\
\text { dimension }\end{array}$ \\
\hline
\end{tabular}

$\mathrm{R}^{2}=. .376$ which mean that the independent

variable explain the change in the dependent

variable at percent $37.6 \%$

\section{c- ANOVA Test:}

table 41

\begin{tabular}{|c|c|c|c|c|c|}
\hline Sig. & $\mathrm{F}$ & Mean Square & $\overline{\mathrm{Df}}$ & Sum of Squares & Model \\
\hline \multirow{3}{*}{0.000} & \multirow{3}{*}{191.417} & 1925.893 & 1 & 1925.893 & Regression \\
\hline & & 10.061 & 318 & 3199.479 & Residual \\
\hline & & & 319 & 5125.372 & Total \\
\hline
\end{tabular}

The previous table clarify that there is positive relation between the two varibles which explained by the value of $\mathrm{F}$ which have significant level .05 .

d- Regression analysis:

table 42

\begin{tabular}{|c|c|c|c|c|c|c|}
\hline \multirow[t]{2}{*}{ Sig. } & \multirow[t]{2}{*}{$\mathrm{T}$} & $\begin{array}{l}\text { Standardized } \\
\text { Coefficients }\end{array}$ & \multicolumn{2}{|c|}{$\begin{array}{l}\text { Unstandardized } \\
\text { Coefficients }\end{array}$} & \multirow{2}{*}{\multicolumn{2}{|c|}{ Model }} \\
\hline & & Beta & Std. Error & B & & \\
\hline 0.000 & 9.235 & & 0.775 & 7.156 & Constant & \\
\hline 0.000 & 13.835 & 0.613 & 0.045 & 0.618 & $\begin{array}{l}\text { Symbol } \\
\text { dimension }\end{array}$ & 1 \\
\hline
\end{tabular}

العدد الر ابع •r.r. 
The effect of organizational culture on strategic thinking - field study ...

Dr/ Amira Said Mohamed Gadelrab

The previous table clarify that $\mathrm{T}$ test for independent variable have significant level at .05 and that clarify the strong relation between two variables .

We can summarize from the previous table the following:

\# pearson and regression variable less than .05 which mean that there is statistical relation between the two variables . \# pearson was positive which mean that there is positive relation between the two variables.

\# Beta clarify that independent variable affect the dependent one at different percentage and that is not by chance

\# from previous the researcher can accept the alternative hypothesis:

" there is significant effect between the two variables "

11- eleventh sub-hypothesis:

There is no significant relation between symbol dimension and depending on hypotheses.

a- Correlation:

table 43

\begin{tabular}{|l|l|l|l|}
\hline Variable & Test & symbol dimension & $\begin{array}{l}\text { Depending on } \\
\text { hypotheses }\end{array}$ \\
\hline symbol dimension & Pearson correlation & 1 & .635 \\
\hline & Sig. & 0.000 & 0.000 \\
\hline
\end{tabular}

العدد الر ابع • r. الع المجلد الحادي عشر 
The effect of organizational culture on strategic thinking - field study ...

Dr/ Amira Said Mohamed Gadelrab

From the previous table its clarify that there is significant relation between two varibles at percent $63.5 \%$

b- Model summary:

table 44

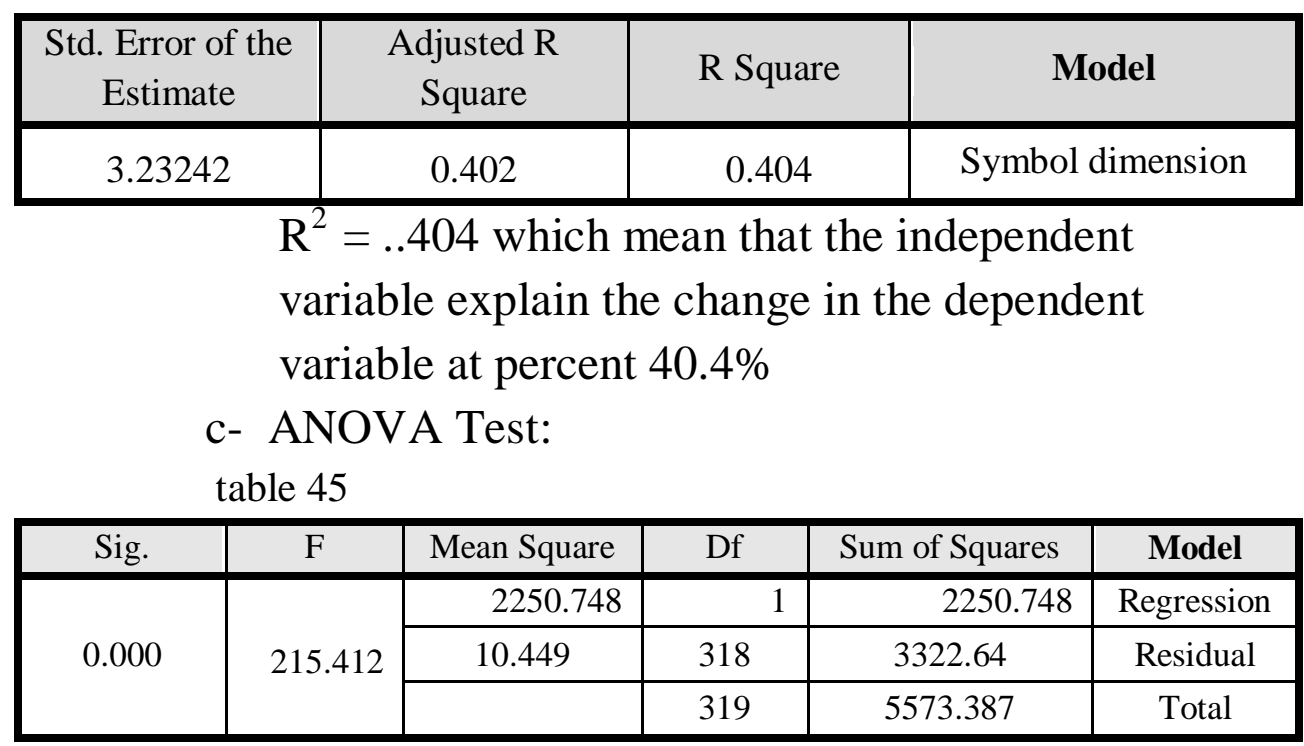

The previous table clarify that there is positive relation

between the two varibles which explained by the value of F which have significant level .05 .

d- Regression analysis:

table 46

\begin{tabular}{|c|c|c|c|c|c|c|}
\hline \multirow[t]{2}{*}{ Sig. } & \multirow[t]{2}{*}{$\mathrm{T}$} & $\begin{array}{l}\text { Standardized } \\
\text { Coefficients }\end{array}$ & \multicolumn{2}{|c|}{$\begin{array}{l}\text { Unstandardized } \\
\text { Coefficients }\end{array}$} & \multirow{2}{*}{\multicolumn{2}{|c|}{ Model }} \\
\hline & & Beta & Std. Error & B & & \\
\hline 0.000 & 7.061 & & 0.79 & 5.575 & Constant & \\
\hline 0.000 & 14.677 & 0.635 & 0.045 & 0.668 & $\begin{array}{l}\text { Symbol } \\
\text { dimension }\end{array}$ & 1 \\
\hline
\end{tabular}

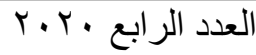


The effect of organizational culture on strategic thinking - field study ...

Dr/ Amira Said Mohamed Gadelrab

The previous table clarify that $\mathrm{T}$ test for independent variable have significant level at .05 and that clarify the strong relation between two variables .

We can summarize from the previous table the following: \# pearson and regression variable less than .05 which mean that there is statistical relation between the two variables . \# pearson was positive which mean that there is positive relation between the two variables.

\# Beta clarify that independent variable affect the dependent one at different percentage and that is not by chance

\# from previous the researcher can accept the alternative hypothesis:

"there is significant effect between the two variables "

12- the twelfth sub-hypothesis:

There is no significant relation between symbol dimension and systematic thinking .

a- Correlation: Table 47

\begin{tabular}{|l|l|l|l|}
\hline Variable & Test & symbol dimension & Systematic thinking \\
\hline symbol dimension & Pearson correlation & 1 & .660 \\
\hline & Sig. & 0.000 & 0.000 \\
& & & \\
\hline
\end{tabular}

From the previous table its clarify that there is significant relation between two varibles at percent $66 \%$

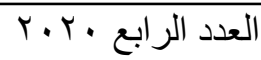
المجلد الحادي عشر 
The effect of organizational culture on strategic thinking - field study ...

Dr/ Amira Said Mohamed Gadelrab

b- Model summary :

table 48

\begin{tabular}{|c|c|c|c|}
\hline Std. Error of the Estimate & Adjusted R Square & R Square & Model \\
\hline 3.3911 & 0.434 & 0.436 & $\begin{array}{c}\text { Symbol } \\
\text { dimension }\end{array}$ \\
\hline
\end{tabular}

$\mathrm{R}^{2}=. .436$ which mean that the independent

variable explain the change in the dependent

variable at percent $43.6 \%$

c- ANOVA Test :

table 49

\begin{tabular}{|c|c|c|c|c|c|}
\hline Sig. & $\mathrm{F}$ & Mean Square & Df & Sum of Squares & Model \\
\hline \multirow{3}{*}{0.000} & \multirow{3}{*}{245.568} & 2823.93 & 1 & 2823.93 & Regression \\
\hline & & 11.5 & 318 & 3656.866 & Residual \\
\hline & & & 319 & 6480.797 & Total \\
\hline
\end{tabular}

The previous table clarify that there is positive relation between the two varibles which explained by the value of $\mathrm{F}$ which have significant level .05 .

d- Regression analysis:

table 50

\begin{tabular}{|c|c|c|c|c|c|c|}
\hline \multirow[t]{2}{*}{ Sig. } & \multirow[t]{2}{*}{$\mathrm{T}$} & $\begin{array}{l}\text { Standardized } \\
\text { Coefficients }\end{array}$ & \multicolumn{2}{|c|}{$\begin{array}{l}\text { Unstandardized } \\
\text { Coefficients }\end{array}$} & \multirow{2}{*}{\multicolumn{2}{|c|}{ Model }} \\
\hline & & Beta & Std. Error & B & & \\
\hline 0.000 & 6.117 & & 0.828 & 5.067 & Constant & \\
\hline 0.000 & 15.671 & 0.660 & 0.048 & 0.748 & $\begin{array}{l}\text { Symbol } \\
\text { dimension }\end{array}$ & 1 \\
\hline
\end{tabular}

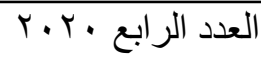


The effect of organizational culture on strategic thinking - field study ...

Dr/ Amira Said Mohamed Gadelrab

The previous table clarify that $\mathrm{T}$ test for independent variable have significant level at .05 and that clarify the strong relation between two variables .

We can summarize from the previous table the following: \# pearson and regression variable less than .05 which mean that there is statistical relation between the two variables . \# pearson was positive which mean that there is positive relation between the two variables.

\# Beta clarify that independent variable affect the dependent one at different percentage and that is not by chance

\# from previous the researcher can accept the alternative hypothesis:

" there is significant effect between the two variables "

\section{3- Thirteenth variable:}

There is no significant relation between support dimension and thinking in time.

a- Correlation:

Table 51

\begin{tabular}{|l|l|l|l|}
\hline Variable & Test & Support dimension & Thinking in time \\
\hline Support dimension & Pearson correlation & 1 & .569 \\
\hline & Sig. & 0.000 & 0.000 \\
\hline
\end{tabular}

From the previous table its clarify that there is significant relation between two varibles at percent $56.9 \%$

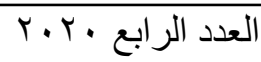

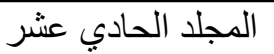


The effect of organizational culture on strategic thinking - field study ...

Dr/ Amira Said Mohamed Gadelrab

b- Model summary:

table 52

\begin{tabular}{|r|r|r|l|}
\hline \multicolumn{1}{|c|}{ Std. Error of the Estimate } & Adjusted R Square & R Square & \multicolumn{1}{|c|}{$\begin{array}{c}\text { Independent } \\
\text { variable }\end{array}$} \\
\hline 3.28439 & 0.322 & 0.324 & $\begin{array}{l}\text { Support } \\
\text { dimension }\end{array}$ \\
\hline
\end{tabular}

$\mathrm{R}^{2}=. .324$ which mean that the independent

variable explain the change in the dependent

variable at percent $32.4 \%$

c- ANOVA TEST:

table 53

\begin{tabular}{|c|c|c|c|c|c|}
\hline Sig. & $\mathrm{F}$ & Mean Square & Df & Sum of Squares & Model \\
\hline \multirow{3}{*}{0.000} & \multirow{3}{*}{152.593} & 1646.054 & 1 & 1646.054 & Regression \\
\hline & & 10.787 & 318 & 3430.334 & Residual \\
\hline & & & 319 & 5076.387 & Total \\
\hline
\end{tabular}

The previous table clarify that there is positive relation

between the two varibles which explained by the value of F which have significant level .05 .

d- Regression analysis:

table 54

\begin{tabular}{|c|c|c|c|c|c|c|}
\hline \multirow[t]{2}{*}{ Sig. } & \multirow[t]{2}{*}{$\mathrm{T}$} & $\begin{array}{l}\text { Standardized } \\
\text { Coefficients }\end{array}$ & \multicolumn{2}{|c|}{$\begin{array}{c}\text { Unstandardized } \\
\text { Coefficients }\end{array}$} & \multirow[t]{2}{*}{ Model } & \\
\hline & & Beta & Std. Error & B & & \\
\hline 0.000 & 6.752 & & 0.891 & 6.018 & Constant & \\
\hline 0.000 & 12.353 & 0.569 & 0.052 & 0.638 & $\begin{array}{l}\text { Support } \\
\text { dimension }\end{array}$ & 1 \\
\hline
\end{tabular}

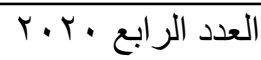


The effect of organizational culture on strategic thinking - field study ...

Dr/ Amira Said Mohamed Gadelrab

The previous table clarify that $\mathrm{T}$ test for independent variable have significant level at .05 and that clarify the strong relation between two variables .

We can summarize from the previous table the following: \# pearson and regression variable less than .05 which mean that there is statistical relation between the two variables . \# pearson was positive which mean that there is positive relation between the two variables.

\# Beta clarify that independent variable affect the dependent one at different percentage and that is not by chance

\# from previous the researcher can accept the alternative hypothesis:

" there is significant effect between the two variables "

14- Fourteenth sub- hypothesis:

There is no significant relation between

support dimension and thinking in

opportunities .

a- Correlation:

table 55

\begin{tabular}{|l|l|l|l|}
\hline Variable & Test & Support dimension & $\begin{array}{l}\text { Thinking in } \\
\text { opportunities }\end{array}$ \\
\hline Support dimension & Pearson correlation & 1 & .606 \\
\hline & Sig. & 0.000 & 0.000 \\
\hline
\end{tabular}

From the previous table its clarify that there is significant relation between two varibles at percent $60.6 \%$

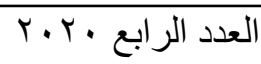


The effect of organizational culture on strategic thinking - field study ...

Dr/ Amira Said Mohamed Gadelrab

b- Model Summary:

table 56

\begin{tabular}{|r|r|r|l|}
\hline Std. Error of the Estimate & Adjusted R Square & R Square & \multicolumn{1}{|c|}{ Model } \\
\hline 3.19263 & 0.366 & 0.368 & $\begin{array}{l}\text { Support } \\
\text { dimension }\end{array}$ \\
\hline
\end{tabular}

$\mathrm{R}^{2}=. .368$ which mean that the independent

variable explain the change in the dependent

variable at percent $36.8 \%$

c- ANOVA TEST:

table 57

\begin{tabular}{|c|c|c|c|c|c|}
\hline Sig. & $\mathrm{F}$ & Mean Square & $\mathrm{Df}$ & Sum of Squares & Model \\
\hline \multirow{3}{*}{0.000} & \multirow{3}{*}{184.839} & 1884.039 & 1 & 1884.039 & Regression \\
\hline & & 10.193 & 318 & 3241.333 & Residual \\
\hline & & & 319 & 5125.372 & Total \\
\hline
\end{tabular}

The previous table clarify that there is positive relation between the two varibles which explained by the value of $\mathrm{F}$ which have significant level .05 .

d- Regression analysis:

Table 58

\begin{tabular}{|c|c|c|c|c|c|c|}
\hline \multirow[t]{2}{*}{ Sig. } & \multirow[t]{2}{*}{$\mathrm{T}$} & \multirow{2}{*}{$\begin{array}{c}\text { Standardized } \\
\text { Coefficients } \\
\text { Beta }\end{array}$} & \multicolumn{2}{|c|}{$\begin{array}{l}\text { Unstandardized } \\
\text { Coefficients }\end{array}$} & \multirow{2}{*}{\multicolumn{2}{|c|}{ Model }} \\
\hline & & & Std. Error & B & & \\
\hline 0.000 & 6.997 & & 0.867 & 6.063 & Constant & \\
\hline 0.000 & 13.596 & 0.606 & 0.05 & 0.682 & $\begin{array}{l}\text { Support } \\
\text { dimension }\end{array}$ & 1 \\
\hline
\end{tabular}

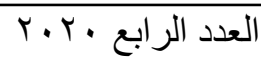


The effect of organizational culture on strategic thinking - field study ...

Dr/ Amira Said Mohamed Gadelrab

The previous table clarify that $\mathrm{T}$ test for independent variable have significant level at .05 and that clarify the strong relation between two variables .

We can summarize from the previous table the following: \# pearson and regression variable less than .05 which mean that there is statistical relation between the two variables . \# pearson was positive which mean that there is positive relation between the two variables.

\# Beta clarify that independent variable affect the dependent one at different percentage and that is not by chance

\# from previous the researcher can accept the alternative hypothesis:

" there is significant effect between the two variables "

15- fifteenth sub-hypothesis:

There is no significant relation between support dimension and depending on hypotheses .

a- Correlation :

table 59

\begin{tabular}{|l|l|l|l|}
\hline Variable & Test & Support dimension & $\begin{array}{l}\text { Depending on } \\
\text { hypotheses }\end{array}$ \\
\hline Support dimension & Pearson correlation & 1 & .539 \\
\hline & Sig. & 0.000 & 0.000 \\
\hline
\end{tabular}

From the previous table its clarify that there is significant relation between two varibles at percent $53.9 \%$

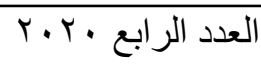


The effect of organizational culture on strategic thinking - field study ...

Dr/ Amira Said Mohamed Gadelrab

b- Model Summary:

table 60

\begin{tabular}{|r|r|r|l|}
\hline $\begin{array}{c}\text { Std. Error of the } \\
\text { Estimate }\end{array}$ & \multicolumn{1}{|c|}{$\begin{array}{c}\text { Adjusted R } \\
\text { Square }\end{array}$} & R Square & Model \\
\hline 3.53737 & 0.286 & 0.291 & Support dimension \\
\hline
\end{tabular}

$\mathrm{R}^{2}=. .291$ which mean that the independent

variable explain the change in the dependent

variable at percent $29.1 \%$

\section{c- ANOVA Test:}

table 61

\begin{tabular}{|c|c|c|c|c|c|}
\hline Sig. & $\mathrm{F}$ & Mean Square & Df & Sum of Squares & Model \\
\hline \multirow{3}{*}{0.000} & \multirow{3}{*}{127.408} & 1594.255 & 1 & 1594.255 & Regression \\
\hline & & 12.513 & 318 & 3979.132 & Residual \\
\hline & & & 319 & 5573.387 & Total \\
\hline
\end{tabular}

The previous table clarify that there is positive relation between the two varibles which explained by the value of $F$ which have significant level .05

d- Regression analysis:

table 62

\begin{tabular}{|c|c|c|c|c|c|c|}
\hline \multirow[t]{2}{*}{ Sig. } & \multirow[t]{2}{*}{$\mathrm{T}$} & $\begin{array}{l}\text { Standardized } \\
\text { Coefficients }\end{array}$ & \multicolumn{2}{|c|}{$\begin{array}{l}\text { Unstandardized } \\
\text { Coefficients }\end{array}$} & \multirow{2}{*}{\multicolumn{2}{|c|}{ Model }} \\
\hline & & Beta & Std. Error & B & & \\
\hline 0.000 & 6.512 & & 0.96 & 6.252 & Constant & \\
\hline 0.000 & 11.288 & 0.539 & 0.056 & 0.628 & $\begin{array}{l}\text { Support } \\
\text { dimension }\end{array}$ & 1 \\
\hline
\end{tabular}

العدد الر ابع • r. ا 
The effect of organizational culture on strategic thinking - field study ...

Dr/ Amira Said Mohamed Gadelrab

The previous table clarify that $\mathrm{T}$ test for independent variable have significant level at .05 and that clarify the strong relation between two variables .

We can summarize from the previous table the following: \# pearson and regression variable less than .05 which mean that there is statistical relation between the two variables . \# pearson was positive which mean that there is positive relation between the two variables.

\# Beta clarify that independent variable affect the dependent one at different percentage and that is not by chance

\# from previous the researcher can accept the alternative hypothesis:

" there is significant effect between the two variables " 16- sixteenth sub-hypothesis:

There is no significant relation between support dimension and systematic thinking .

a- Correlation:

table 63

\begin{tabular}{|l|l|l|l|}
\hline Variable & Test & Support dimension & Systematic thinking \\
\hline Support dimension & Pearson correlation & 1 & .599 \\
\hline & Sig. & 0.000 & 0.000 \\
\hline
\end{tabular}

From the previous table its clarify that there is significant relation between two varibles at percent $59.9 \%$

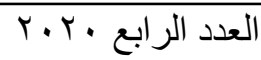

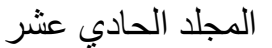


The effect of organizational culture on strategic thinking - field study ...

Dr/ Amira Said Mohamed Gadelrab

b- Model Summary:

table 64

\begin{tabular}{|r|r|r|l|}
\hline Std. Error of the Estimate & Adjusted R Square & R Square & \multicolumn{1}{|c|}{ Model } \\
\hline 3.6147 & 0.357 & 0.359 & $\begin{array}{l}\text { Support } \\
\text { dimension }\end{array}$ \\
\hline
\end{tabular}

$\mathrm{R}^{2}=. .359$ which mean that the independent

variable explain the change in the dependent

variable at percent $35.9 \%$

c- ANNOVA TEST:

table 65

\begin{tabular}{|c|c|c|c|c|c|}
\hline Sig. & $\mathrm{F}$ & Mean Square & $\mathrm{Df}$ & Sum of Squares & Model \\
\hline \multirow{3}{*}{0.000} & \multirow{3}{*}{178.003} & 2325.792 & 1 & 2325.792 & Regression \\
\hline & & 13.066 & 318 & 4155.004 & Residual \\
\hline & & & 319 & 6480.797 & Total \\
\hline
\end{tabular}

The previous table clarify that there is positive relation between the two varibles which explained by the value of $F$ which have significant level .05

d- Regression analysis:

table 66

\begin{tabular}{|c|c|c|c|c|c|c|}
\hline \multirow{2}{*}{ Sig. } & \multirow{2}{*}{$\mathrm{T}$} & $\begin{array}{c}\text { Standardized } \\
\text { Coefficients }\end{array}$ & \multicolumn{2}{|c|}{$\begin{array}{c}\text { Unstandardized } \\
\text { Coefficients }\end{array}$} & \multicolumn{2}{|c|}{ Model } \\
\cline { 4 - 6 } & & Beta & Std. Error & \multicolumn{1}{|c|}{$\mathrm{B}$} & \multicolumn{2}{|c|}{} \\
\cline { 4 - 6 } & & & 0.981 & 4.895 & Constant & \\
\cline { 1 - 4 } 0.000 & 4.989 & & 0.057 & 0.758 & $\begin{array}{l}\text { Support } \\
\text { dimension }\end{array}$ & 1 \\
\hline
\end{tabular}

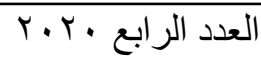


The effect of organizational culture on strategic thinking - field study ...

Dr/ Amira Said Mohamed Gadelrab

The previous table clarify that $\mathrm{T}$ test for independent variable have significant level at .05 and that clarify the strong relation between two variables .

We can summarize from the previous table the following:

\# pearson and regression variable less than .05 which mean that there is statistical relation between the two variables .

\# pearson was positive which mean that there is positive relation between the two variables.

\# Beta clarify that independent variable affect the dependent one at different percentage and that is not by chance

\# from previous the researcher can accept the alternative hypothesis:" there is significant effect between the two variables “

Finding:

1- According to findings the first sub hypothesis was refused and accept the alternative hypothesis .

2- the second sub hypothesis was refused and accept the alternative hypothesis .

3- the third sub hypothesis was refused and accept the alternative hypothesis .

4- the forth sub hypothesis was refused and accept the alternative hypothesis .

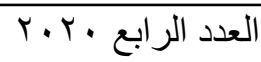
المجلد الحادي عشر 
The effect of organizational culture on strategic thinking - field study ...

Dr/ Amira Said Mohamed Gadelrab

5- the fifth sub hypothesis was refused and accept the alternative hypothesis .

6- the sixth sub hypothesis was refused and accept the alternative hypothesis .

7- the seventh sub hypothesis was refused and accept the alternative hypothesis .

8- the eighth sub hypothesis was refused and accept the alternative hypothesis .

9- the ninth sub hypothesis was refused and accept the alternative hypothesis .

10- the tenth sub hypothesis was refused and accept the alternative hypothesis .

11- the eleventh sub hypothesis was refused and accept the alternative hypothesis .

12- the twelfth sub hypothesis was refused and accept the alternative hypothesis .

13- the thirteenth sub hypothesis was refused and accept the alternative hypothesis

14- the fourteenth sub hypothesis was refused and accept the alternative hypothesis

15- the fifteenth sub hypothesis was refused and accept the alternative hypothesis ..

16- the sixteenth sub hypothesis was refused and accept the alternative hypothesis .

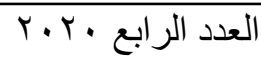
المجلد الحادي عشر 
The effect of organizational culture on strategic thinking - field study ...

Dr/ Amira Said Mohamed Gadelrab

and by this the researcher can refuse the main

hypothesis and accept the main alternative hypothesis.

\section{Refrence:}

Abbas Monnavarian, Gita Farmani and Hajar Yajam, Strategic thinking in Benetton, BUSINESS STRATEGY SERIESjVOL. 12 NO. 22011

Aqueeb Sohail Shaik and Sanjay Dhir, A meta-analytical review of factors

affecting the strategic thinking of an organization, FORESIGHT $\mathrm{j}$ VOL. 22 NO. 2 2020, pp. 144-177

Felin, T., \& Powell, T. (2016). Designing Organizations for Dynamic

Capabilities. California Management Review, 58(4), 78-96. doi: 10.1525/cmr.2016.58.4.78

Goldman , Leadership practices that encourage strategic thinking, Journal of Strategy and Management Vol. 5 No. 1, 2012 pp. 25-40

Graetz, Strategic thinking versus strategic planning: towards understanding the complementarities , Management Decision 40/5[2002]456 \pm 462

Iraj Tavakoli and Judith Lawton, Strategic thinking and knowledge management , HANDBOOKOFBUSINESSSTRATEGY , 2005

KPMG Australia. (2018). Succeeding in disruptive times. Sydney: KPMG International Cooperative. Retrieved from https://home.kpmg.com/au/en/home/insights/2016/05/globaltransformation-study-2016.html 5/amr.2001.5393897

Sini , Evaluation of strategic thinking and its affecting factors among managers and personnel in a medical sciences university in Iran, INTERNATIONAL JOURNAL OF HUMAN RIGHTS IN HEALTHCARE j VOL. 10 NO. 4 2017, pp. 248-255,

Wolters, Grome and Hinds 2013 , Exploring Strategic Thinking: Insights to Assess, Develop, and Retain Army Strategic Thinkers, United States Army Research Institute for the Behavioral and Social Sciences

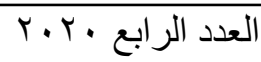

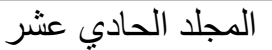

901 